\title{
Spectrum of ovarian tumors in a referral hospital in Nepal
}

\author{
Vaidya $\mathrm{S},{ }^{1}$ Sharma $\mathrm{P},{ }^{2} \mathrm{KC} \mathrm{S},{ }^{3}$ Vaidya $\mathrm{SA}^{4}$ \\ ${ }^{I}$ Department of Pathology, Kathmandu Medical College, Kathmandu, Nepal \\ ${ }^{2}$ Department of Obstetrics and Gynaecology, Patan Academy of Health Sciences, Lalitpur, Nepal \\ ${ }^{3}$ Department of Pathology, Patan Academy of Health Sciences, Lalitpur, Nepal \\ ${ }^{4}$ Department of Obstetrics and Gynaecology, Maternity Hospital, Kathmandu, Nepal
}

\section{Keywords: \\ Benign; \\ Borderline; \\ Malignant; \\ Ovarian tumor.}

\begin{abstract}
Background: Ovarian tumors are common forms of neoplasia in women. Among cancers of the female genital tract, it ranks only below carcinoma of the cervix and the endometrium, but is responsible for approximately $50 \%$ of the deaths. They arise from different cell lineages and hence constitute a wide variety of neoplastic entities with diverse morphological and clinical manifestations.
\end{abstract}

Materials and Methods: A descriptive study of 363 cases of ovarian tumors was carried out during a three year period from January 2011 to December 2013.

Results: Of the 363 ovarian tumors, 293 (80.72\%) cases were benign, 57 (15.70\%) were malignant and $13(3.58 \%)$ were borderline. Germ cell tumour was the most common class of tumour and seen in $187(51.52 \%)$ cases, followed by surface epithelial in $158(43.53 \%)$ cases. The age distribution of the patients ranged from 10-82 years with a median age of 33 years. Benign tumors were more common than malignant ones in all age groups.

Conclusion: Most of the ovarian tumors in this study were of germ cell origin. The incidence of malignant germ cell tumors was also significantly higher than in other studies. Mature cystic teratoma was the most common benign tumour while serous carcinoma was the most common malignancy. The incidence of malignant germ cell tumors was higher compared to other studies.

\section{INTRODUCTION}

Ovarian tumors are common forms of neoplasia in women. ${ }^{1}$ They arise from different cell lineages and hence constitute a wide variety of neoplastic entities with diverse morphological and clinical manifestations. Ovarian cancer

\footnotetext{
Correspondence:

Dr. Sujan Vaidya, $M D$

Department of Pathology,

Kathmandu Medical College, Kathmandu, Nepal

E-mail:vaidyasujan@gmail.com
}

accounts for $15-25 \%$ of all gynaecological malignancies, yet it is responsible for approximately $50 \%$ of the deaths. ${ }^{2,3}$ Among cancers of the female genital tract, the incidence of ovarian cancer ranks only below carcinoma of the cervix and the endometrium. ${ }^{4}$ As early ovarian cancer is not associated with significant symptoms, most women present with advanced disease. 5 The recognition of the various histological patterns is important for correct diagnosis, which has important implications for treatment and prognosis. 
The present study was undertaken so as to find out the frequency of different histological types of ovarian tumors which are prevalent in this part of the country and to seen whether they are significantly different from other populations.

\section{MATERIALS AND METHODS}

This is a descriptive study conducted in the department of pathology, Patan Academy of Health Sciences from January 2011 to December 2013. This study included all consecutive cases of ovarian tumors reported in the Department of Pathology over a three year period were included in the study. Tumour-like conditions were excluded from the study. The tumors were classified according to the World Health Organization classification of ovarian tumors. ${ }^{7}$ Statistical analyses were done by statistical package for social sciences (SPSS) version 17.

\section{RESULTS}

A total of 363 ovarian tumors were diagnosed in the three year period. Amongst them, 293 (80.72\%) were benign, 13 $(3.58 \%)$ were borderline while $57(15.70 \%)$ were malignant. Germ cell tumour was the most common class of tumor and seen in $187(51.52 \%)$ cases, followed by surface epithelial $158(43.53 \%)$ tumors (Table 1$)$.
Table 1: Frequency of different classes of ovarian tumors

\begin{tabular}{lcc}
\hline \multicolumn{1}{c}{ Class of tumor } & No. & $\mathbf{\%}$ \\
\hline Germ cell tumour & 187 & 51.52 \\
Surface epithelial tumour & 158 & 43.53 \\
Sex cord-stromal tumour & 12 & 3.30 \\
Secondary (metastatic) tumour & 6 & 1.65 \\
\hline Total & 363 & 100 \\
\hline
\end{tabular}

Of the 293 benign tumors, $169(57.68 \%)$ were germ cell tumors while 117 (39.93\%) were surface epithelial tumors. Out of the 57 malignant tumors, $28(49.12 \%)$ were surface epithelial tumors while $18(31.58 \%)$ were of germ cell origin (Table 2).

Out of the 158 surface epithelial tumors, 117 (74\%) were benign, $13(8.23 \%)$ were borderline whereas $28(17.72 \%)$ were malignant. Most of these tumors were of serous and mucinous origin and were seen in $92(58.23 \%)$ and 57 $(36.08 \%)$ cases, respectively (Table 2$)$.

Out of the 187 germ cell tumors, 169 (90.37\%) were benign, most being mature cystic teratomas $(98.82 \%)$. Immature teratoma was the commonest germ cell malignancy and seen in $9(50 \%)$ cases.

Table 2: Histological pattern of ovarian tumors

\begin{tabular}{|c|c|c|c|c|}
\hline Diagnosis & Benign & Borderline & Malignant & Total \\
\hline Surface Epithelial Tumour & 117 & 13 & 28 & 158 \\
\hline Serous tumour & 72 & 3 & 17 & 92 \\
\hline Mucinous tumour & 42 & 10 & 5 & 57 \\
\hline Endometrioid tumour & - & - & 4 & 4 \\
\hline Malignant mixed mullerian tumour & - & - & 2 & 2 \\
\hline Brenner tumour & 1 & - & - & 1 \\
\hline Mixed epithelial tumour & 2 & - & - & 2 \\
\hline Sex Cord-Stromal Tumour & 7 & - & 5 & 12 \\
\hline Adult granulosa cell tumour & - & - & 4 & 4 \\
\hline Juvenile granulosa cell tumour & - & - & 1 & 1 \\
\hline Fibroma & 5 & - & - & 5 \\
\hline Thecoma & 1 & 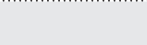 & & 1 \\
\hline Sclerosing stromal tumour & 1 & - & - & 1 \\
\hline Germ Cell Tumour & 169 & - & 18 & 187 \\
\hline Dysgerminoma & - & - & 2 & 2 \\
\hline Yolk sac tumour & - & - & 2 & 2 \\
\hline Mature cystic teratoma & 167 & - & - & 167 \\
\hline Struma ovarii & 2 & - & - & 2 \\
\hline Immature teratoma & - & - & 9 & 9 \\
\hline $\mathrm{SCC}$ arising from a dermoid cyst & - & - & 3 & 3 \\
\hline Malignant mixed germ cell tumour & - & - & 2 & 2 \\
\hline Secondary (metastatic) tumour & - & - & 6 & 6 \\
\hline Grand Total & 293 & 13 & 57 & 363 \\
\hline
\end{tabular}


Table 3: Frequency of different classes of ovarian tumors in different age groups

\begin{tabular}{|c|c|c|c|c|c|c|c|c|c|}
\hline Classes of tumors & Total & Types & $<\mathbf{2 0}$ & $20-29$ & 30-39 & $40-49$ & $50-59$ & $\geq 60$ & Total \\
\hline Surface epithelial & & Benign & 5 & 27 & 31 & 20 & 18 & 16 & 117 \\
\hline \multirow[t]{2}{*}{$(\mathrm{n}=158)$} & 158 & Borderline & - & - & 5 & 3 & 3 & 2 & 13 \\
\hline & & Malignant & 2 & 3 & 3 & 6 & 10 & 4 & 28 \\
\hline Sex cord-stromal & & Benign & - & 2 & 1 & - & 3 & 1 & 7 \\
\hline$(\mathrm{n}=12)$ & 12 & Malignant & - & 3 & - & 2 & - & - & 5 \\
\hline Germ cell & 187 & Benign & 12 & 69 & 54 & 21 & 9 & 4 & 169 \\
\hline$(\mathrm{n}=187)$ & & Malignant & 3 & 8 & 3 & 2 & 1 & 1 & 18 \\
\hline \multicolumn{10}{|l|}{ Secondary } \\
\hline$(n=6)$ & 6 & Malignant & - & 1 & 2 & 1 & 2 & - & 6 \\
\hline Total & 363 & & 22 & 113 & 99 & 55 & 46 & 28 & 363 \\
\hline
\end{tabular}

Table 4: Unilateral and bilateral distribution of ovarian tumors

\begin{tabular}{|c|c|c|c|c|}
\hline Tumour Type & Diagnosis & $\mathbf{U} / \mathbf{L}$ & $B / L$ & Tota \\
\hline \multirow{10}{*}{ Benign } & Serous cystadenoma & 68 & 4 & 72 \\
\hline & Mucinous cystadenoma & 40 & 2 & 42 \\
\hline & Brenner tumour & 1 & - & 1 \\
\hline & Mixed epithelial tumors & 2 & - & 2 \\
\hline & Fibroma & 5 & - & 5 \\
\hline & Thecoma & 1 & - & 1 \\
\hline & Sclerosing stromal tumour & 1 & - & 1 \\
\hline & Mature cystic teratoma & 150 & 17 & 167 \\
\hline & Struma ovarii & 2 & - & 2 \\
\hline & Total & 270 & 23 & 113 \\
\hline \multirow{3}{*}{ Borderline } & Borderline serous tumour & 3 & - & 3 \\
\hline & Borderline mucinous tumour & 10 & - & 10 \\
\hline & Total & 13 & - & 13 \\
\hline \multirow{13}{*}{ Malignant } & Serous cystadenocarcinoma & 11 & 6 & 17 \\
\hline & Mucinous cystadenocarcinoma & 3 & 2 & 5 \\
\hline & Endometrioid carcinoma & 1 & 3 & 4 \\
\hline & Malignant mixed mullerian tumour & 1 & 1 & 2 \\
\hline & Adult granulosa cell tumour & 4 & - & 4 \\
\hline & Juvenile granulosa cell tumour & 1 & - & 1 \\
\hline & Dysgerminoma & 2 & - & 2 \\
\hline & Yolk sac tumour & 2 & - & 2 \\
\hline & Immature teratoma & 9 & - & 9 \\
\hline & SCC arising from a dermoid cyst & 3 & - & 3 \\
\hline & Malignant mixed germ cell tumour & 1 & 1 & 2 \\
\hline & Secondary (metastatic) tumors & 1 & 5 & 6 \\
\hline & Total & 39 & 18 & 57 \\
\hline
\end{tabular}

Amongst the 12 sex-cord stromal tumors, 7 (58.33\%) were benign and $5(41.67 \%)$ malignant (Table 2). Overall, mature cystic teratoma was the most common benign tumour and was seen in 167/293 (57\%) cases. Mucinous borderline tumour was more prevalent in the borderline category and seen in $10 / 13(76.92 \%)$ cases. Serous carcinoma was the most common malignancy and seen in $17 / 57$ (29.82\%) patients (Table 2).

The age distribution of the patients for all tumors ranged from 10-82 years with a median age of 33 years. Similarly, the median age for benign tumors was 32 years, while for borderline and malignant tumors it was 47 and 40 years, respectively. Approximately, 212(58.40\%) tumors were 
seen in the 20-40 year age group. Benign tumors were more common than malignancies in all age groups. Most benign tumors $(68.60 \%)$ were diagnosed in the $3 \mathrm{rd}$ and 4 th decades of life, whereas most malignant tumors $(50.88 \%)$ were seen after the 4th decade, with the exception of malignant germ cell tumors which were mostly seen below the age of 30 $(77.78 \%)$. Borderline tumors were only seen after the age of 30 (Table 3).

Up to the $1^{\text {st }}$ four decades, germ cell tumour was the predominant class of tumour and was seen in 149/234 (63.68\%) cases. Both benign and malignant germ cell tumors were more prevalent in the 20-29 year age group and were seen in 69/169 (40.83\%) and 8/18 (44.44\%) cases, respectively. Also, amongst the 5 malignancies seen below the age of 20, $3(60 \%)$ cases were of germ cell origin (Table $3)$.

From the $4^{\text {th }}$ decade onwards, surface epithelial tumors were more common and seen in 82/129 (63.57\%) cases. Twenty $(71.43 \%)$ cases of malignant surface epithelial tumors were seen after the $4^{\text {th }}$ decade, of which $11(55 \%)$ cases were serous carcinomas. Out of the 12 sex cord-stromal tumors, 5 (41.67\%) were seen in the 20-29 age group. All 6 secondary (metastatic) tumors occurred after the 2nd decade and were almost evenly distributed amongst the other age groups (Table 3).

Out of the 363 ovarian tumors, $41(11.29 \%)$ cases were bilaterally involved by the tumour. It was observed in $31.58 \%$ (18 cases) malignant tumors compared to just $7.85 \%$ (23 cases) in benign tumors. Most of the secondary (metastatic) tumors $(83.33 \%)$ and endometrioid carcinomas $(75 \%)$ were bilateral. All 13 borderline tumors were unilateral (Table 4).

\section{DISCUSSION}

In this study, $80.72 \%(\mathrm{n}=292)$ of the ovarian tumors were benign. This is similar to data from the west and the subcontinent, including Nepal., ${ }^{4,-12}$ The frequency of borderline and malignant tumors in the subcontinent was variable from 0.72 to $4.33 \%$ and 9.5 to $30.96 \%$, ${ }^{9-}$ ${ }^{16}$ respectively. In our study, mature cystic teratoma was the most common benign tumour (57\%) where as serous carcinoma was the commonest malignancy $(29.82 \%)$. Similar findings were reported in other studies. ${ }^{9,10,17,18}$

Germ cell tumors constitute $15-30 \%$ of all ovarian tumors. ${ }^{1,17}$ However, in one North American study, the figure was surprisingly high $58 \%{ }^{18}$ Similar high incidence of $51.52 \%$ was also observed in our study. About $95 \%$ of these tumors are benign (predominantly mature cystic teratomas) $9,10,17,18$ while the incidence of malignant ovarian germ cell tumors ranges from 1 to $6 \%$ as reported in the west ${ }^{1,7,19,20}$ and from 5 to $20 \%$ in Asia. ${ }^{9,11,21-24}$ In our study, the incidence of benign germ cell tumors was similar to the numbers reported elsewhere. However, the incidence of germ cell malignancies was much higher accounting for $31.58 \%$ of all ovarian cancers.

In the western literature, surface epithelial tumors account for 50 to $55 \%$ of all ovarian tumors while their malignant counterparts comprise approximately $90 \%$ of all ovarian cancers. ${ }^{17,18}$ Data from similar studies in Japan and Nepal show that 46 to $52 \%$ of ovarian tumors are surface epithelial in origin, where as their malignancies account for 69 to $75 \%$ of all ovarian cancers. ${ }^{8-10,21,25}$ However, in our study both these figures were much lower $(43.53 \%$ and $49.12 \%$, respectively). In the subcontinent, the corresponding figures varied from 61.6 to $90 \%$ and 67.44 to $85.71 \%$, respectively. ${ }^{6,11,13,14}$

Serous tumors constitute about $30 \%$ of all ovarian tumors, of which approximately $60 \%$ are benign, $10 \%$ borderline while $30 \%$ are malignant., ${ }^{4,17}, 18$ In our study, serous tumors accounted for $25.34 \%$ of all ovarian tumors. This figure varied from $32.35 \%$ to $50.8 \%$ in other studies. ${ }^{9,10,13}$ In our study, $78.26 \%$ of the serous tumors were benign, $3.26 \%$ borderline and $18.48 \%$ malignant.

Likewise, mucinous tumors account for 12 to $25 \%$ of all ovarian tumors, which is similar to our $(15.70 \%)$ and other studies from the subcontinent. ${ }^{9,10,13}$ Approximately $75 \%$ of these tumors are benign, $10 \%$ borderline and $15 \%$ are malignant. ${ }^{4,17,18}$ In our study, $73.69 \%$ of these tumors were benign, $17.54 \%$ were borderline and only $8.77 \%$ cases were malignant.

In the literature, $5-12 \%$ of all ovarian tumors are sex cord stromal tumors ${ }^{17,18}$ and $7-12.5 \%$ are secondary tumors. ${ }^{26}$ In our study, sex cord stromal and secondary (metastatic) tumors accounted for only $3.3 \%$ and $1.65 \%$, respectively. According to Scully et $a{ }^{8}{ }^{8}$ approximately $70 \%$ of the secondary (metastatic) tumors are bilateral, where as it was $83.33 \%$ in our study.

In agreement with other studies, most ovarian tumors were seen in the reproductive age group, between 20-40 years. ${ }^{9,11}$ Benign tumors of all were seen in all age groups. Malignant surface epithelial tumors occurred mostly after the 4th decade. Similar observations were also made in other studies. $^{8-10}$ In patients under the age of 21 years, approximately $60 \%$ of the ovarian tumors are of germ cell origin, and as many as one third of germ cell tumors are malignant, accounting for two thirds of ovarian cancers in the first two decades. ${ }^{27}$ In our study, $68.18 \%$ of the tumors seen in this age group were of germ cell origin and $20 \%$ of these germ cell tumors were malignant. 


\section{CONCLUSION}

In our study, most of the tumors were of germ cell origin. The incidence of malignant germ cell tumors was higher than in other studies. Mature cystic teratoma was the most common benign tumour while serous carcinoma was the commonest malignancy. Benign tumors were more common than malignancies in all age groups. Malignant surface epithelial tumors were mostly seen after the $4^{\text {th }}$ decade while malignant germ cell tumors were observed in a younger age group.

\section{REFERENCES}

1. Young RH, Clement PB, Scully RE. Pathology of the ovary, In: Sternberg SS, ed. Diagnostic Surgical Pathology. Vol. 2. Raven Press: New York; 1994. pp 2195-279.

2. Benson RC. Diagnosis and treatment. Current Obstet Gynaecol 1976;1:236.

3. Ramzy I. Essentials of Gynecologic and Obstetric Pathology. Appleton Century Crofts: Connecticut; 1983.p 231.

4. Crum CP. The Female Genital Tract, In: Robbins and Cotran (eds). Pathologic Basis of Disease. 7th ed. Saunders: Philadelphia, Pennsylvania; 2004.pp1092-117.

5. Partridge EE, Phillips JL, Menck HR. The national cancer database reports on ovarian cancer treatment in United States hospitals. Cancer 1996;24:2236-46. CrossRef

6. Shah S, Hishikar VA. Incidence and management of ovarian tumors. Bombay Hospital Journal 2008;50:30-3.

7. Tavasolli FA, Devilee P, (eds). WHO Classification of Tumors. Pathology and Genetics, Tumors of Breast and Female Genital Organs. IARC Press: Lyon; 2003. p114.

8. Scully RE, Young RH, Clement PB, (eds). Tumors of the ovary, maldeveloped gonads, fallopian tube and broad ligament, Atlas of Tumor Pathology. 3rd series, Fascicle 23. Armed Forces Institute of Pathology: Washington, D.C;1999.

9. Jha R, Karki S. Histological pattern of ovarian tumors and their age distribution. Nepal Med Coll J 2008;10:81-5. PMid:18828427

10. Amatya S, Gurung G, Rana A. Annual Clinicopathological Analysis of Ovarian tumors at TUTH. Nepal Journal of Obstetrics and Gynaecology 2010;4:18-24.

11. Khan AA, Luqman M, Jamal S, Mamoon N, Mushtaq S. Clinicopathological analysis of ovarian tumors. Pak J Pathol 2005;16:28-32.

12. Pilli GS, Suneeta KP, Dhaded AV, Yenni VV. Ovarian tumors: A study of 282 cases. J Indian Med Assoc 2002;100:423-4. PMid:12674165

13. Shaikh NA, Hashmi F, Samoo RP. Pattern of Ovarian Tumors: Report of 15 years experience at Liaquat University Jamshoro. JLUMHS
2007;13-5.

14. Bhattacharya MM, Shinde SD, Purandare VN. A clinicopathological analysis of 270 ovarian tumors. Journal of Postgraduate Medicine 1980;26:103-7. PMid:7218168

15. Ahmed M, Malik TM, Afzal S, Mubarik A. Clinicopathological study of 762 ovarian neoplasms at Army Medical College Rawalpindi. Pakistan J Pathol 2004; 15:147-52.

16. Gupta N, Bisht D, Agarwal AK, Sharma VK. Retrospective and prospective study of ovarian tumous and tumor-like lesions. Indian Journal of Pathology and Microbiology 2007;50:525-7. PMid:17883123

17. Katsube Y, Berg JW, Silverberg SG. Epidemiologic pathology of ovarian tumors: a histopathologic review of primary ovarian neoplasms diagnosed in the Denver standard metropolitan statistical area, 1 July - 31 December 1969 and 1 July -31 December 1979. Int J Gynecol Pathol 1982;1:3-16. CrossRef

18. Koonings PP, Campbell K, Mishell DR Jr, Grimes DA. Relative frequency of primary ovarian neoplasms: a 10-year review. Obstet Gynae 1989;74:921-6.

19. Gershenson DM. Management of early ovarian cancers: germ cell and sex cord-stromal tumors. Gynecol Oncol 1994;55:62-72. CrossRef

20. Weiss NS, Homonchuk T, Young JL. Incidence of the histologic type of ovarian cancer. Gynecol Oncol 1977;5:161-7. CrossRef

21. Nakashima N, Nagasaka T, Fukata S, et al. Study of ovarian tumors treated at the Nagoya University Hospital, 1965-1988.Gynecol Oncol 1990;37:103-11. CrossRef

22. Singh P, Ilancheran A, Singh P, Tan BY, Tock PC, Ratnam SS. Ovarian cancer in Oriental women from Singapore. Int. Surg 1990;75:115-22. PMid:2379990

23. Jamal S, Quddusi H, Mehmood A. A clinicopathological analysis of 110 ovarian tumors. Pakistan J Med Sci 1997;14:19-23.

24. Muzaffar A, Malik IA, Asraf S. A clinicopathological analysis of 107 ovarian tumors. Pakistan J Med Assoc 1987;37:194-7.

25. Tateno H, Sasano N. Ovarian tumors in Sendai, Japan. General hospital material. In: Stalsberg H, ed. An international survey of distributions of histologic types of tumors of the testes and the ovary. UICC technical report series, vol 75. Geneva: UICC, 1983.pp291-6.

26. Moore RG, Chung M, Granai GO, Gajewski W, Steinhoff MM: Incidence of metastasis to the ovaries from nongenital tract tumors. Gynecol Oncol, 2004;93:87-91. CrossRef

27. Lack EE, Goldstein DP. Primary ovarian tumors in childhood and adolescence. Current Prob Obstet Gynecol 1984;7:8. 